\title{
Sustainability of Small Reservoirs and Large Scale Water Availability Under Current Conditions and Climate Change
}

\author{
Maarten S. Krol • Marjella J. de Vries • \\ Pieter R. van Oel - José Carlos de Araújo
}

Received: 15 February 2010 / Accepted: 3 February 2011 /

Published online: 5 April 2011

(C) The Author(s) 2011. This article is published with open access at Springerlink.com

\begin{abstract}
Semi-arid river basins often rely on reservoirs for water supply. Small reservoirs may impact on large-scale water availability both by enhancing availability in a distributed sense and by subtracting water for large downstream user communities, e.g. served by large reservoirs. Both of these impacts of small reservoirs are subject to climate change. Using a case-study on North-East Brazil, this paper shows that climate change impacts on water availability may be severe, and impacts on distributed water availability from small reservoirs may exceed impacts on centralised water availability from large reservoirs. Next, the paper shows that the effect of small reservoirs on water availability from large reservoirs may be significant, and increase both in relative and absolute sense under unfavourable climate change.
\end{abstract}

Keywords Small reservoirs $\cdot$ Water availability $\cdot$ Climate change $\cdot$ Semi-arid

\section{Introduction}

In semi-arid river basins, small-scale reservoirs are often numerous. This paper assesses large scale (river basin scale) effects of small scale reservoirs. Relevant large scale effects of these reservoirs are basically twofold:

- firstly, small reservoirs retain water, enabling local distributed usage, and thereby subtract it from availability to the largest and concentrated uses downstream in the river basin, e.g. facilitated through a large scale reservoir downstream in the basin,

M. S. Krol (凶) · M. J. de Vries · P. R. van Oel

Department of Water Engineering and Management, University of Twente,

Enschede, The Netherlands

e-mail: m.s.krol@utwente.nl

J. C. de Araújo

Universidade Federal do Ceará, Fortaleza, Brazil 
- secondly, small reservoirs enhance distributed water availability, an effect accumulating to a large scale effect at the scale of the river basin, through the large numbers of reservoirs, and through its' dominant role as the source of water availability in locations, relatively upstream in the river basin.

In North-East Brazil, and various other semi-arid regions, small scale reservoirs are so numerous, that their effect is expected to be significant (De Araújo and González Piedra 2009; Ngigi 2003; van Oel et al. 2008). In a basin, reservoir density is considered high, when reservoir capacity exceeds $40 \%$ of average runoff (USBR 2002), a situation plausibly nearing basin closure (Molle 2004), as an indicator for unsustainable human interference in the river basin. In the same time, however, the representation of small reservoirs in large-scale hydrological models is, at best, implicit (Güntner et al. 1999, 2004).

This paper investigates an explicit representation of small reservoirs for evaluation of water management at a large scale, using a case study under current and possible future climate conditions. The case study concerns the Benguê catchment in NorthEast Brazil (Gaiser et al. 2003); regional climate change scenarios base on results of modelling studies reported on in the Fourth Assessment Report of IPCC (IPCC 2007).

The goals of reservoirs for water storage are manifold, ranging from guaranteeing water supply, via generating electricity or protecting against flooding up to perennizing river flow (WCD 2000). These goals are generally pursued within the delineation of a river basin, which often shows a fractal-like structure, where the basin can be divided into sub-basins at many different scales; the goals of reservoirs can be pursued at the various scales, consistently involving reservoirs of various scales (van Oel 2009).

River basin management (RBM) and integrated water resources management (IWRM) call for an integrated consideration of water related issues, societal stakes as well as aspects of spatio-temporal distribution in designing and implementing water-related policies. Drawing on common pool resources theory (Ostrom et al. 1999), factors enhancing the manageability of reservoirs depend on scale in various, opposing ways (van Oel 2009), and may have significant externalities towards downstream (van Oel et al. 2008).

Tools to support the design of such policies include physical water balance models of the river basin, implicitly or explicitly representing hydrological responses, water use issues and operation of water infrastructure. Here, we use a hydrological model to drive the explicit routing of water in a river-reservoir network. Simulations are interpreted to large scale water availability, both as large scale distributed availability, and availability in large scale reservoirs for usage downstream.

The effect of small reservoirs is addressed by comparing simulations for situations with and without small reservoirs. The analysis is performed under a set of climate assumptions, adding potential changes in both precipitation and evapotranspiration.

The analyses are done for a case study basin in semi-arid North-East Brazil. The performance of the hydrological schematizations is evaluated by comparing simulations to monitored storage in the large basin downstream.

Conclusions on the sensitivity of large scale water availability to developments in the number of small reservoir, and to changes in various climate variables are discussed on their general applicability. 


\section{Hydrological Model and Indicators for Water Availability}

The WASA model (Güntner 2002; Güntner and Bronstert 2004), developed mostly for the Brazilian state of Ceará, describes the water cycle in river basins, simulating the water balance of soils and water reservoirs, generation of run-off and routing of flow through the river network, in which the reservoirs are located, using data sources listed in Table 1.

The vertical hydrology is represented on spatial units, defined by properties concerning soil, vegetation cover and topographic position in the terrain. These units are treated as sub-basins. Soil moisture, in a location-dependent number of soil horizons, changes due to infiltration of precipitation, runoff generation, evapotranspiration, deep percolation and moisture redistribution. The model allows for lateral exchanges between units. Runoff results at surface and subsurface levels when soil moisture exceeds the water holding capacity, or when rainfall exceeds infiltration capacity.

Runoff is described to accumulate in a stream network at a sub-basin scale and to become available by fractions for storage in smaller reservoirs at that scale. These smaller reservoirs are represented in 5 size classes (from $<0.1 \mathrm{Mm}^{3}$ to $10-50 \mathrm{Mm}^{3}$ ) in a lumped way, and each class is assumed to receive 1/6th of the locally generated runoff; the last $1 / 6$ th flowing into the main river network connecting the subbasins. Outflow or overflow of small reservoirs is routed to be equally divided over the larger reservoir classes and the main river network. Eventually, runoff and reservoir overflow/outflow enter the river network.

Dams with reservoirs larger than $50 \mathrm{Mm}^{3}$ are represented to intersect the main river network and may thereby store flow originating from upstream sub-basins as well.

Reservoir water balances of both smaller and larger reservoirs account for inflow, direct precipitation, evaporation, infiltration, withdrawal from the reservoir, controlled release, and overflow.

The WASA model is largely process-based. Regional data availability at the resolution of the model was very limited, making the application of conceptual or empirical models (like HBV (Bergström 1992) or the SCS-approach (SCS 1972)) very difficult in this context, reducing their ability to reliably represent the water balance of the region under strongly changing conditions. Process descriptions in the model were chosen on their particular applicability under semi-arid conditions, leading to deviations in descriptions compared to e.g. Topmodel (Beven and Kirkby 1979) or SWIM (Krysanova et al. 2005).

The model was applied to the Benguê catchment (Fig. 1), a $933 \mathrm{~km}^{2}$ area with the $19.6 \mathrm{Mm}^{3}$ Benguê-reservoir at the outlet (Creutzfeld 2006); the reservoir is designed to have a water yield of $200 \mathrm{~L} / \mathrm{s}$. Within the catchment, 133 reservoirs are identified,

Table 1 Spatial data used in the WASA model (Güntner 2002)

\begin{tabular}{lll}
\hline Theme & Scale & Source \\
\hline Topography Digital Elevation Model & Grid spacing 30 arcsec & (USGS 1999) \\
Vegetation & $1: 1$ million & (MDME 1981a, b) \\
Soil associations, landscape units & $1: 1$ million & (Jacomine et al. 1973) \\
Geomorphology, topography & $1: 1$ million & (MDME 1981a, b) \\
Climate & Station data, interpolated & (Gerstengarbe and Werner 2002) \\
Reservoirs & Municipality & (SRH 1992) \\
\hline
\end{tabular}




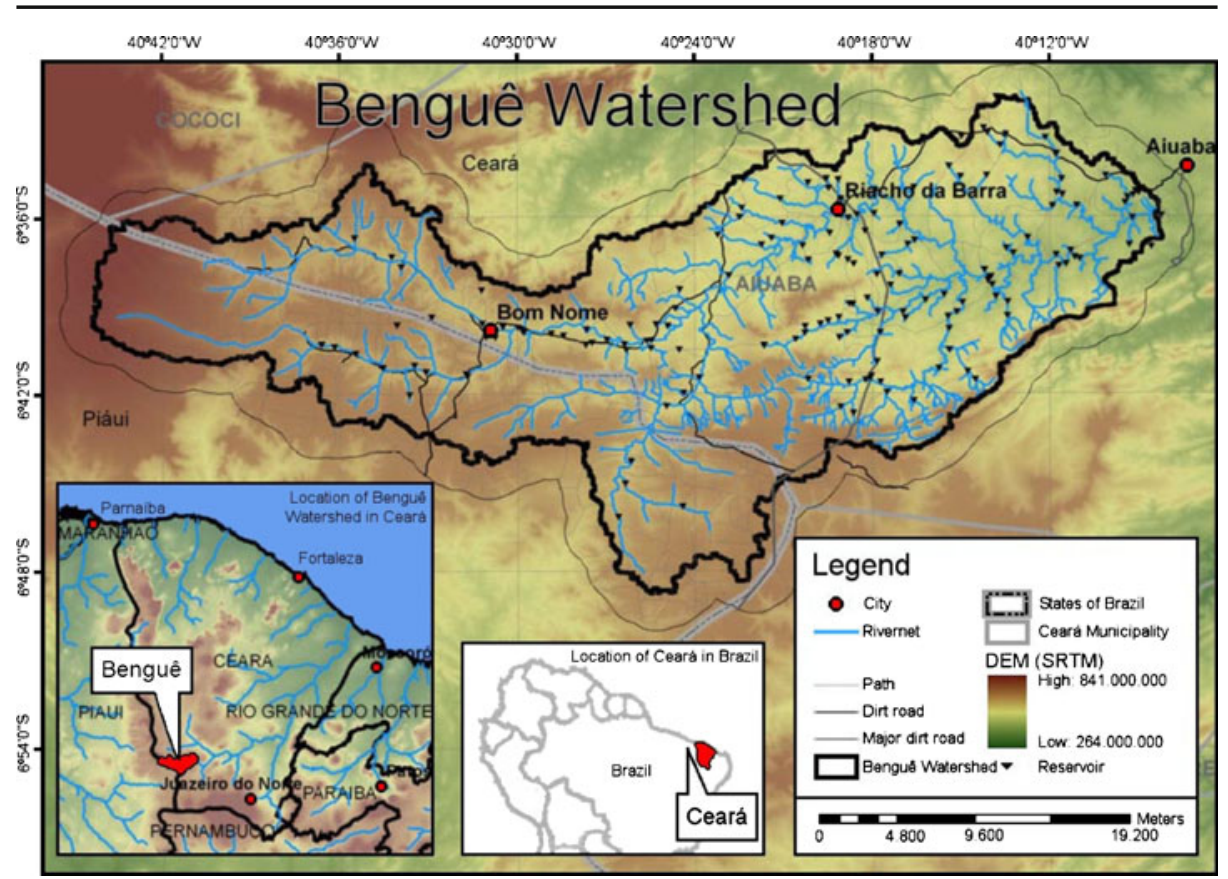

Fig. 1 Benguê watershed (Creutzfeld 2006)

of which 113 have a capacity below $0.1 \mathrm{Mm}^{3}, 17$ between 0.1 and $1 \mathrm{Mm}^{3}$, one between 1 and $2.5 \mathrm{Mm}^{3}$, and two between 5 and $10 \mathrm{Mm}^{3}$; their total capacity (excluding the Benguê-reservoir) is about $21.5 \mathrm{Mm}^{3}$.

In the current paper, runoff is routed to and between reservoirs in an explicit scheme, based on the locations of the reservoirs and a geohydromorphological analysis of the basin using the Digital Elevation Model.

The model used meteorological data from FUNCEME (2008) and Gerstengarbe and Werner (2002). Annual precipitation averages $565 \mathrm{~mm}$ (ranging between 210 and $1265 \mathrm{~mm}$ from 1979 to 2006), while potential evapotranspiration averages 2,200 $\mathrm{mm}$.

The combination of low precipitation, high infiltration and large reservoir capacity imply a categorization of the basin hydrology as highly affected by the small reservoirs using a definition entailing a threshold of $40 \%$ of runoff for total reservoir capacity (USBR 2002).

A comparison of observed and simulated values for storage in the Benguê reservoir for the period 2000-2005 shows, that the geo-explicit model with the input data used yields a qualitatively reasonable but quantitatively quite poor simulation of the dynamics of reservoir storage (Fig. 2), possibly due to biased precipitation/local runoff data.

Models simulations are interpreted as water availability in two ways, relating to the two aspects of large scale water availability distinguished here.

1. The water availability related to large-scale use downstream, achieved through a strategic reservoir, is often referred to as reservoir yield and quantified as the constant controlled outflow that can be guaranteed in $90 \%$ of the years, 


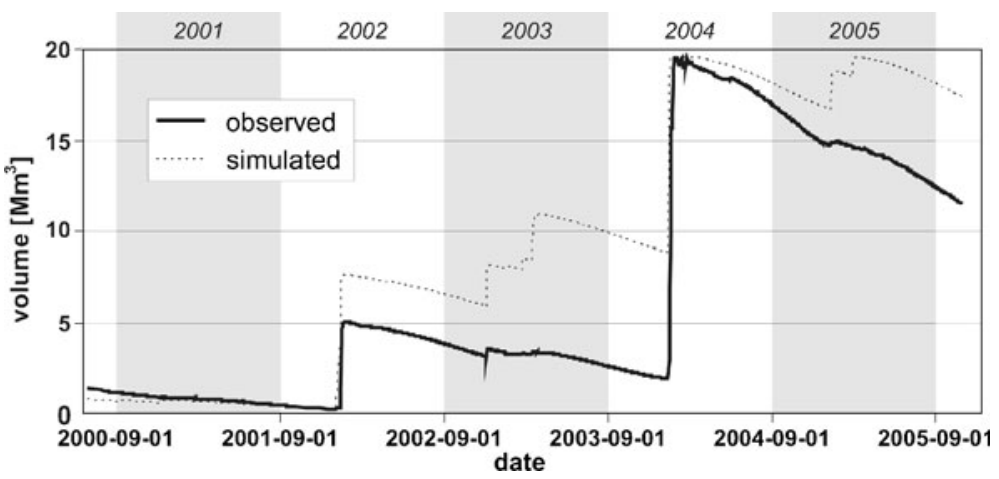

Fig. 2 Volume of water stored in the Benguê reservoir, as observed (ANA 2005; COGERH 2002, 2003) and as simulated using hydrologic input from WASA (Güntner 2002) and explicit routing through the 133 reservoir network. Grey and white bands indicate hydrological years

depending on the stochastic characteristics of inflow. An algorithm to determine this reservoir yield, using statistical properties of reservoir inflow, precipitation and evaporation, and based on the regionally applied method of Campos (1987) is described in van Oel et al. (2008).

2. The large scale distributed water availability within the basin is assessed using the total water storage in the smaller reservoirs, upstream from the Benguê-reservoir as an indicator.

The sensitivity of large scale water availability for climate change was assessed by evaluating both indicators for current climate and under possible future conditions.

\section{Climate Scenarios and Regional Model Skill}

Climate scenarios were drawn from the third (TAR) and fourth (AR4) IPCC assessment reports IPCC $(2001,2007)$. The skill of global circulation models (GCMs) to represent the regional climate of the semi-arid North-East Brazil is evaluated by comparing the simulations of annual and dry season precipitation to the observed climatology; models contributing to the third assessment report (IPCC 2001) have been analysed earlier (Krol et al. 2003). Here evaluations of models contributing to the fourth assessment report were added. The climatology used in the comparison is New et al. (1999).

The skill of a model, to represent regional climate, is here evaluated by its simulations of annual precipitation and dry season precipitation (and thus its seasonality), and defined as

Model_skill

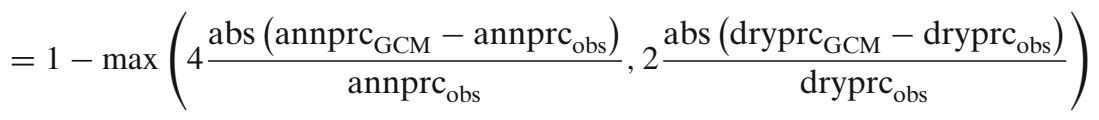

where annprc denotes annual precipitation, dryprc dry season precipitation (JuneNovember) and the values 4 and 2 are weights for the severity of model deviations. 
Consistent with the observations in Krol et al. (2003), Fig. 3 shows that, for the GCMs contributing to the TAR, only a limited number of models shows a positive skill, and that these models inhibit strongly deviating climate change signals, ranging from $-50 \%$ to $+20 \%$ change in annual precipitation by the year 2100 for a high emissions scenario. For the AR4-contributing models, again a small number of models show a positive skill for representing the regional climate of Northeast Brazil. The models with a reasonable skill however, are unanimous on a modest climate change effect in annual precipitation, projections ranging from $-8 \%$ to $+6 \%$ by the year 2100 for a high emissions scenario. Strong regional precipitation change signals are still found in model simulations, ranging from $-35 \%$ to $+35 \%$ by the year 2100 for a high emissions scenario, but these signals result from models with a modest model skill in representing NEB climate.

Next to the precipitation change, changes in other meteorological variables may significantly affect the functioning of surface storage facilities.

Particularly, as projected precipitation changes have become modest in skill-full models contributing to AR4, we here address the effect of changes in potential evapotranspiration PET and reference evaporation $\mathrm{ET}_{0}$, for which models consistently project increases of up to $15 \%$ by 2100 . In the WASA model, increases in evapotranspiration affect the water balance in the spatial units in the area, reducing run-off to the stream and river network and the reservoirs. Moreover, increases in reference evaporation increase the evaporative losses from the reservoir itself, as is accounted for both in the WASA model and in the adapted Campos method to determine reservoir yield.

The climate scenarios to assess regional sensitivity are chosen as firstly, a $10 \%$ reduction in precipitation, being the worst precipitation trend for reasonably skilled models; secondly, a 15 increase in reference evaporation, and thirdly, the combination of these two changes.

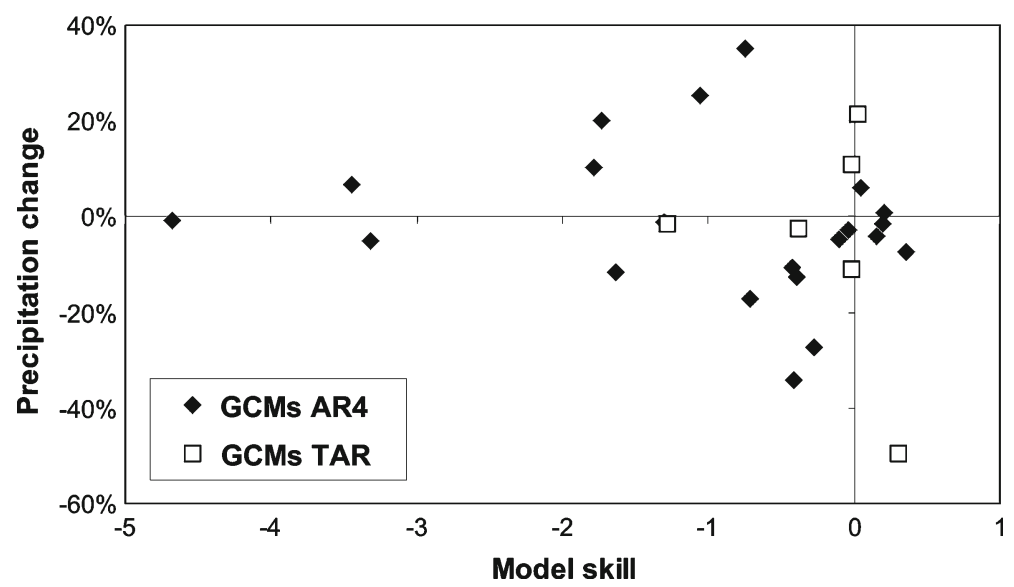

Fig. 3 Changes in precipitation in semi-arid Northeast Brazil by 2100, as projected by GCMs for high emissions scenarios, as a function of model skill to represent regional climate. Results were taken of models contributing to IPCC assessments; TAR denotes the third assessment report (IPCC 2001), AR4 denotes the fourth assessment report (IPCC 2007) 
Table 2 Changes in water storage in small reservoirs and large reservoir yield under different assumptions of climate change

\begin{tabular}{llll}
\hline & Annprc $-10 \%$ & $\mathrm{ET}_{0}+15 \%$ & Both changes \\
\hline Storage in small reservoirs & $-27 \%$ & $-32 \%$ & $-53 \%$ \\
Yield strategic reservoir & $-19 \%$ & $-16 \%$ & $-38 \%$ \\
\hline
\end{tabular}

Additionally, to assess the influence of the impact of small reservoirs on large reservoirs, simulations were done in the original setting, and for a situation without small reservoirs.

\section{Results}

Simulations of the hydrological model, with routing into and through the reservoir network, yield an appreciable sensitivity of both aspects of large scale water availability to potential climate changes.

The distributed large scale water availability, through storage in small reservoirs, is almost equally sensitive to the plausible reduction in precipitation as to the plausible increase in evaporation, with a combined effect of a loss of over half of the stored water volume (Table 2).

The large scale availability (largely towards downstream) in the strategic reservoir is found to be appreciably sensitive too, with the effect of both factors similar as well, combining into a reservoir yield loss of over one third.

The distributed availability is found to be more sensitive to climate change than the availability towards downstream is.

The effect of the small reservoirs on the strategic reservoir can be observed from the reservoir yield of the strategic reservoir.

Table 3 illustrates how small reservoirs in the Benguê catchment reduce the potential reservoir yield by $10 \%$ for the current climate, and by up to $17 \%$ for a plausible future climate with decreased precipitation and increased evaporation.

In absolute terms, the negative impact of the small reservoirs on the yield even increases from $45 \mathrm{~L} / \mathrm{s}$ to $55 \mathrm{~L} / \mathrm{s}$, when the climate change would materialize, even while this climate change would reduce the yield already. The negative effects of climate change and upstream losses thus enhance each other in a way that supersedes linear superposition.

With the current density of small reservoirs, the plausible potential impact of climate change is larger than the effect of the small reservoirs (about twice as large).

Table 3 Reservoir yield of the strategic reservoir under assumptions of climate (columns) and small reservoirs (rows), and absolute and relative impacts of small reservoirs

\begin{tabular}{lcccc}
\hline Yield strategic reservoir & Original climate & prc $-10 \%$ & PET +15\% & Both changes \\
\hline No small reservoirs & $465 \mathrm{~L} / \mathrm{s}$ & $385 \mathrm{~L} / \mathrm{s}$ & $395 \mathrm{~L} / \mathrm{s}$ & $315 \mathrm{~L} / \mathrm{s}$ \\
With small reservoirs & $420 \mathrm{~L} / \mathrm{s}$ & $340 \mathrm{~L} / \mathrm{s}$ & $350 \mathrm{~L} / \mathrm{s}$ & $260 \mathrm{~L} / \mathrm{s}$ \\
Effect small reservoirs & $-45 \mathrm{~L} / \mathrm{s}$ & $-45 \mathrm{~L} / \mathrm{s}$ & $-45 \mathrm{~L} / \mathrm{s}$ & $-55 \mathrm{~L} / \mathrm{s}$ \\
& $-10 \%$ & $-12 \%$ & $-11 \%$ & $-17 \%$ \\
\hline
\end{tabular}




\section{Conclusions}

Climate change projections for North Eastern Brazil using global GCMs contributing to the IPCC-AR4 (IPCC 2007) still vary from significant decreases to significant increases in precipitation. Contrary to the GCMs contributing to the IPCC-TAR (IPCC 2001) however, the models contributing to IPCC-AR4 with the best skill in representing the regional semi-arid climate of North-East Brazil, tend to show modest trends in regional precipitation.

Impacts of climate on drought and on the large-scale effect of small reservoirs may depend at least equally strongly on the changes in evaporation and evapotranspiration (as affected by temperature, humidity, and radiation) as on the changes in precipitation. Skills of current global climate models to represent the sub-continental climate of Northeast Brazil does not allow for firm conclusions, but tend to imply an increase in dryness and in the large-scale effects of small reservoirs.

Both water availability by storage in small reservoirs and the yield of large reservoirs are strongly sensitive to plausible climate changes.

Large scale distributed water availability, supplied by storage in small reservoirs is more vulnerable than large scale availability towards downstream, supplied by storage in large scale strategic reservoirs.

Distributed water availability may halve, due to climate change, indicating that small reservoirs could only sustainably supply water, if water use intensities drop or reservoir numbers increase. Increasing the number of reservoirs regionally is the historically common way to react to undersupplies of water; this strategy would be deemed ineffective however, as even for current climate reservoir capacity is of the same order of magnitude as accumulated basin runoff.

Large scale water availability may reduce by over one third, even when assuming that upstream users do not guarantee their water supply by increasing storage capacity. Downstream water use may therefore be sustainably met, if use intensities drop, or additional water supply sources are installed.

Small reservoirs have a significant effect on the water yield of the strategic reservoir, and this effect is simulated to even increase under disadvantageous climate changes. The combined effect of small reservoirs and climate change is larger than the superposition of their individual effects.

Scenario studies of regional development (Döll and Krol 2002), including both changes in population, land use and climate change, indicate that both concentrations of activities in locations more downstream in the basin, as distributed developments may occur. In all scenarios with disadvantageous climate developments, large dams or inter-basin transfers are suggested to be plausible, and to possibly compensate for the increases in demand.

Under disadvantageous climate development, upstream small scale water users may be expected to compensate for their loss in water availability by increasing the upstream storage capacity in small reservoirs (van Oel 2009). This would enhance the climate change effect on strategic reservoirs.

Acknowledgements The authors thank the SESAM project, in particular Benjamin Creutzfeld and Eva Müller (University of Potsdam, Germany), Andreas Güntner (GFZ German Research Centre for Geosciences, Potsdam, Germany), and the Companhia de Gestão dos Recursos Hídricos (COGERH, Fortaleza, Brazil) for their cooperation and data. 
Open Access This article is distributed under the terms of the Creative Commons Attribution Noncommercial License which permits any noncommercial use, distribution, and reproduction in any medium, provided the original author(s) and source are credited.

\section{References}

ANA (2005) Monitoramento dos Reservatórios do Nordeste. Agência Nacaional de Águas, Brasília Bergström S (1992) The HBV model—its structure and applications. SMHI, Norköping

Beven KJ, Kirkby MJ (1979) A physically based, variable contributing area model of basin hydrology. Hydrol Sci Bull 24(1):43-70

Campos JNB (1987) A procedure for reservoir sizing on intermittent rivers under high evaporation rate. Colorado State University, Fort Collins

COGERH (2002) Anuário do Monitoramento Quantitativo dos Principais Açudes do Estado do Ceará. Companhia de Gestão dos Recursos Hídricos, Fortaleza

COGERH (2003) Anuário do Monitoramento Quantitativo dos Principais Açudes do Estado do Ceará. Companhia de Gestão dos Recursos Hídricos, Fortaleza

Creutzfeld BNA (2006) Remote sensing based characterisation of land cover and terrain properties for hydrological modelling in the semi-arid Northeast of Brazil. University of Potsdam, Potsdam

de Araújo JC, González Piedra GI (2009) Comparative hydrology: analysis of a semiarid and a humid tropical watershed. Hydrol Process 23(8):1169-1178

Döll P, Krol MS (2002) Integrated scenarios of regional development in two semi-arid states of northeastern Brazil. Integrated Assessment 3(4):308-320

FUNCEME (2008) Séries históricas de dados pluviométricos, edited, Fundação Cearense de Meteorologia e Recursos Hídricos

Gaiser T, Krol MS, Frischkorn H, De Araújo JC (eds) (2003) Global change and regional impacts: water availability and vulnerability of eco-systems and society in the semiarid Northeast of Brazil, Springer, Berlin, pp 428

Gerstengarbe F-W, Werner PC (2002) Climate scenarios and climate modelling. In: Gaiser T et al (eds) Global change and regional impacts: water availability and vulnerability of ecoysstems and society in the semi-arid Northeast of Brazil. Springer, Berlin

Güntner A (2002) Large-scale hydrological modelling in the semi-arid North-East of Brazil. Universität Potsdam, Potsdam, pp 148

Güntner A, Bronstert A (2004) Representation of landscape variability and lateral redistribution processes for large-scale hydrological modelling in semi-arid areas. J Hydrol 297(1-4):136-161

Güntner A, Hauschild M, Heinrichs G, Jaeger A, Bronstert A, Döll P, Forster M, Krol M, Gil MML (1999) Integrated modelling of water availabilty and water use at different scales in the semiarid Northeast of Brazil., paper presented at Deutscher Tropentag 1999 in Berlin, Humboldt Universität zu Berlin, Germany

Güntner A, Krol MS, De Araujo JC, Bronstert A (2004) Simple water balance modelling of surface reservoir systems in a large data-scarce semiarid region. Hydrological Sciences Journal-Journal Des Sciences Hydrologiques 49(5):901-918

IPCC (2001) Climate change 2001: the scientific basis. In: Contribution of working group I to the third assessment report of the intergovernmental panel on climate change. Cambridge University Press, Cambridge, pp 881

IPCC (2007) Climate change 2007: the physical science basis. Contribution of working group I to the fourth assessment report of the intergovernmental panel on climate change. Cambridge University Press, Cambridge, pp 996

Jacomine PKT, Almeida JC, Medeiros LAR (1973) Levantamento exploratório-Reconhecimento de colos do Estado do Ceará. Boletim Téchnico No 28. Recife, Brazil

Krol MS, Jaeger A, Bronstert A (2003) Integrated modelling of climate change impacts in Northeastern Brazil. In: Gaiser T et al (eds) Global change and regional impacts: water availability and vulnerability of eco-systems and society in the semiarid Northeast of Brazil. Springer, Berlin, pp 43-56

Krysanova V, Hattermann F, Wechsung F (2005) Development of the ecohydrological model SWIM for regional impact studies and vulnerability assessment. Hydrol Process 19(3):763-783

MDME (1981a) Levantamento de recursos naturais-Projecto Radambrasil, vol 23. Folhas SB 24/25 (Jaguaribe/Natal) 
MDME (1981b) Levantamento de recursos naturais_-Projecto Radambrasil, vol 21. Folhas SA 24 (Fortaleza)

Molle F (2004) Technical and institutional responses to basin closure in the Chao Phraya river basin, Thailand. Water Int 29(1):70-80

New M, Hulme M, Jones P (1999) Representing twentieth-century space-time climate variability. Part I: development of a 1961-90 mean monthly terrestrial climatology. J Clim 12(3):829-856

Ngigi SN (2003) What is the limit of up-scaling rainwater harvesting in a river basin? Phys Chem Earth, Parts A/B/C 28(20-27):943-956

Ostrom E, Burger J, Field CB, Norgaard RB, Policansky D (1999) Sustainability-revisiting the commons: local lessons, global challenges. Science 284(5412):278-282

SCS (1972) Soil conservation service national engineering handbook, Sec. 4. Hydrology, USA

SRH (1992) Plano estadual dos recursos hídricos, vol 2. estudo de base II, Fortaleza, Brazil

USBR (2002) Avaliação de pequenas barragens. Bureau of reclamation, Brasília, Brazil

USGS (1999) Global 30 arc second elevation data set, edited, USGS Eros Data Center

van Oel PR (2009) Water-scarcity patterns: spatiotemporal interdependencies between water use and water availability in a semi-arid river basin. University of Twente, Enschede

van Oel PR, Krol MS, Hoekstra AY, de Araujo JC (2008) The impact of upstream water abstractions on reservoir yield: the case of the Oros Reservoir in Brazil. Hydrological Sciences JournalJournal Des Sciences Hydrologiques 53(4):857-867

WCD (2000) Dams and development. A new framework for decision-making. Earthscan, London, pp 404 